\title{
Alterations in insulin-like growth factor binding protein-3 proteolysis and complex formation in the arthritic joint
}

\author{
E J Whellams ${ }^{1}$, L A Maile ${ }^{1}$, J K Fernihough ${ }^{2}$, M E J Billingham ${ }^{2}$ \\ and J M P Holly ${ }^{\mathbf{1}}$ \\ ${ }^{1}$ University of Bristol, Department of Surgery, Division of Hospital Medicine, Bristol Royal Infirmary, Level 7, Bristol BS2 8HW, UK \\ ${ }^{2}$ Oscor Facility, University of Bristol, Vet School, Southwell St, Bristol BS2 8EJ, UK \\ (Requests for offprints should be addressed to EJ Whellams; Email: Emma.J.Whellams@bristol.ac.uk)
}

\begin{abstract}
Increased concentrations of insulin-like growth factor (IGF) system components have previously been observed in rheumatoid arthritis (RA) and osteoarthritis (OA); however, disruption of the IGF axis and the implications for the disease process remain largely unaddressed. This study was undertaken to characterise the IGF binding protein (IGFBP)-3 proteolysis and complex formation systems in synovial fluid and to investigate changes in these systems in arthritic disease, and their impact on the availability of IGF. Western blotting or autoradiography of SDS gels was used to visualise IGFBP-3 or its proteolysis. IGF-I and IGFBP-3 concentrations were determined by radioimmunoassays and acid-labile subunit (ALS) was measured by ELISA. A shift in distribution of IGFBP-3 and IGF-I in RA and OA synovial fluids (RASynF, OASynF) and an associated increase in ALS suggested the presence of $150 \mathrm{kDa}$ ternary complexes. IGFBP-3 proteolysis was decreased in RASynF and OASynF, but was
\end{abstract}

apparent in size-fractionated fluid and resembled serum activity. The presence of serum-like inhibitors of IGFBP-3 proteolysis in RASynF was also demonstrated by the ability of this fluid, and $150 \mathrm{kDa}$ fractions from its size fractionation, to inhibit IGFBP-3 proteolysis in the other synovial fluid. A marked disruption in the IGF system was observed, as considerably more IGF-I was retained in ternary complexes. We also classified the IGFBP-3 proteolysis system in synovial fluid and found it to be disturbed in RASynF and OASynF. These changes may be caused by an increased flux of circulatory proteins into synovial fluid, resulting from an inflammation-induced increase in vascular permeability. The net result in RA and OA would be a decrease in IGF availability in arthritic joints, and therefore loss of a potential anabolic stimulus. This disruption to the IGF axis would influence disease progression in RA and OA.

Journal of Endocrinology (2000) 165, 545-556

\section{Introduction}

The turnover of matrix proteoglycans by chondrocytes and the presence of an intact collagen network maintain the structural and functional integrity of articular cartilage tissue (McQuillan et al. 1986a, Hardingham et al. 1992). These processes are controlled by hormones, cytokines and growth factors (Trippel 1995), which may be produced locally or delivered from the circulation via synovial fluid, which bathes the avascular cartilage (Morales \& Hascall 1989, Schalkwijk et al. 1989). The homeostatic mechanisms that normally maintain tissue integrity are disrupted in arthritic diseases (Morales \& Hascall 1989, Trippel 1995): catabolic pathways in the joint space exceed anabolism in osteoarthritis (OA), and tissue invasive processes occur in rheumatoid arthritis (RA). The result is degradation of cartilage matrix and decreased synthesis of proteoglycans (Mow et al. 1992, Fassbender 1994). This cartilage damage and loss causes deterioration of joint function, characteristic in RA and OA (Harris 1990, Howell \& Pelletier 1993).

The predominating invasive and degradative processes of RA and OA are believed to be stimulated by mechanical load changes and the presence of soluble mediators in the joint (Mow et al. 1992). Cellular alterations, such as formation of invasive pannus from synovial membrane in RA (De Keyser et al. 1995), possible changes in chondrocyte activities in OA (Mow et al. 1992) and infiltration of inflammatory cells in both diseases (Verschure et al. 1996), produce matrix-degrading molecules and increase cytokines such as interleukin-1 (IL-1) and tumour necrosis factor- $\alpha$ (Van de Loo et al. 1995, Verschure et al. 1996). These cytokines may also significantly increase production of cartilage matrix degradative enzymes, such as collagenase and stromelysin, increasing the ratio of these enzymes compared with tissue inhibitors of these metalloproteinases (Dean et al. 1989, Lefebvre et al. 1990, MacNaul et al. 1990, Mort et al. 1993). In addition, they 
may mediate and maintain inflammation, and IL-1 may inhibit proteoglycan synthesis (Morales \& Hascall 1989, Hardingham et al. 1992). Conversely, anabolic growth factors with the ability to stimulate cartilage matrix production would seem also to have a role in the arthritic disease process. Growth factors such as insulin-like growth factor-I (IGF-I), epidermal growth factor, and transforming growth factor- $\beta$ are believed to control proteoglycan synthesis and cartilage homeostasis (Trippel 1995, Verschure et al. 1996). Increases in their concentrations have been reported in OA and RA (Fernihough et al. 1996, Kusada et al. 1993, Szekanecz et al. 1995), but appear unable to increase anabolic mechanisms to equal or outstrip the catabolic processes.

A role for the IGFs in maintaining cartilage homeostasis has been suggested by a number of in vitro studies. IGF-I has been shown to be a potent stimulator of chondrocyte proliferation (Vetter et al. 1986) and type II collagen and large proteoglycan production (Willis \& Liberti 1985, McQuillan et al. 1986b) for cartilage matrix synthesis. IGF receptors are present on chondrocytes (Dore et al. 1994) and IGF-I is believed to act synergistically with other growth factors (Morales \& Hascall 1989, Trippel 1995). In addition, it has been shown that IGF-I may partially combat the effects of IL-1 in vitro (Tyler 1989), having implications in cytokine-driven aspects of the arthritic disease process. In vivo reports on IGF-I concentrations in cartilage matrix have suggested that the low levels present could indicate a limited role for this growth factor (Schneiderman et al. 1995), but there is evidence to suggest that disruption to the IGF system could play an important role in the pathogenesis of both OA and RA.

The IGF family is composed of the two ligands (IGFs-I and -II) and at least six high-affinity binding proteins (IGFBPs). In the circulation IGFs-I and -II are predominantly found bound to IGFBP-3 and the acid-labile subunit (ALS), forming a circulating reservoir of IGF. This ternary complex extends the half-life of the IGFs, but its size $(150 \mathrm{kDa})$ means it is predominantly restricted to the vasculature. The IGFBPs have a greater affinity for the IGFs than has the IGF cell-surface receptor. Dissociation of IGF from complexes is therefore believed to be achieved by proteolysis of the IGFBPs by specific proteases (for review see Jones \& Clemmons 1995), as first described in pregnancy serum (Hossenlopp et al. 1990). This decreases the affinity of the IGFBPs for the IGFs and makes the ligand more available to bind its receptor and exert anabolic or mitogenic effects.

We have previously measured components of the IGF system in synovial fluid taken from normal, OA and RA joints and found the system to be considerably disrupted (Fernihough et al. 1996). Concentrations of the two peptides, IGFs-I and -II, are considerably increased in OA and RA compared with normal. However, concentrations of the major binding protein IGFBP-3 are also greatly increased. This causes a shift in the molar ratio of IGF to binding protein so that, in $\mathrm{OA}$ and $\mathrm{RA}$, there is a molar excess of IGFBP-3 to IGF, whereas the reverse is true in normal synovial fluid (NSynF) samples. In addition, there is a decrease in measurable protease activity against IGFBP-3 in RA synovial fluid (RASynF) and OA synovial fluid (OASynF), despite the increased amount of degradative enzymes present in arthritic synovial fluid (Dean et al. 1989, Fowlkes et al. 1994). This implies that, despite an increase in the anabolic peptides IGF-I and -II in RA and OA, they are bound to high-affinity IGFBP-3 and are unable to bind to their cell receptors.

Despite the knowledge of alterations in the IGF system, the cause of these changes and their implication for the arthritic disease process has been largely unaddressed. In this study we have attempted to characterise the change in complex formation of IGF system components and to investigate disruption to the IGFBP-3 proteolysis system in the arthritic joint. We have also looked at their impact on the availability of IGF. The link to inflammation, known to occur extensively in RA disease (Harris 1990) and evident in varying degrees and stages of $\mathrm{OA}$ disease (Pelletier et al. 1993), has also been discussed as a possible mediator of IGF system changes.

\section{Materials and Methods}

\section{Materials}

All chemicals unless otherwise stated were from Sigma (Poole, Dorset, UK). Dr C A Maack (Celtrix Pharmaceuticals, Santa Clara, CA, USA) provided recombinant non-glycosylated IGFBP-3 (ngIGFBP-3). IGFBP-3 polyclonal antibody ( $\mathrm{SCH} 2 / 6)$ was raised in our laboratory.

\section{Samples}

Informed consent was obtained from all subjects and the fluid collection was approved by the ethics committee of the United Bristol Healthcare Trust.

Normal adult serum A serum pool was made from 25 healthy volunteers. Serum was separated immediately at $4{ }^{\circ} \mathrm{C}$ and stored at $-20{ }^{\circ} \mathrm{C}$.

Serum from pregnant women A serum pool was made from 10 patients in the third trimester of pregnancy. Serum was separated immediately at $4{ }^{\circ} \mathrm{C}$ and stored at $-20{ }^{\circ} \mathrm{C}$.

Synovial fluid Synovial fluid pools were prepared from fluid obtained by aspiration of the knee joints of 15 patients with OA (mean age $66 \pm 7$ years), and 15 patients with RA (mean age $56 \pm 15$ years). All patients met American College of Rheumatology criteria for disease (Altman et al. 1986, Arnett et al. 1988). Synovial fluid was also obtained 
from three normal volunteers by aspiration of the suprapatella pouch, and at post mortem examination (within $8 \mathrm{~h}$ of death) of five individuals with no history of joint disease and macroscopical normal joint tissue; a pool of NSynF was prepared from these samples (mean age of normal group $52 \pm 22$ years). The fluid was centrifuged to remove cells and stored at $-70{ }^{\circ} \mathrm{C}$.

Pooled fluid samples To ensure that the pooled fluids used in this study were representative of the individual samples, IGFBP-3 western immunoblots (methodology as used for distribution of IGFBP-3 in column fractions) were performed before use of the pools. These confirmed that similar IGFBP-3 fragmentation patterns (or lack of them), were present in individual samples for each fluid type. In addition, two individual samples of each fluid type were size-separated as detailed below and used to confirm all results obtained with the pooled fluid samples.

\section{Size separation of serum and physiological fluids}

A Superose 12 column was used for the separation of fluids, and was calibrated using a molecular weight marker kit, molecular weight range 12000 to 200000 (Sigma, Poole, Dorset, UK). This determined the approximate size of molecules that retained in vivo associations, in the fractions collected. Serum from normal adults and synovial fluids (pre-digested with hyaluronidase for $20 \mathrm{~min}$ at $37^{\circ} \mathrm{C}$ ) were filtered through a $0 \cdot 22 \mu \mathrm{m}$ filter before size fractionation under neutral conditions. Aliquots $(100 \mu \mathrm{l})$ of sample were loaded onto the Superose 12 column in a $0.05 \mathrm{M}$ phosphate, $0 \cdot 1 \mathrm{M}$ sodium chloride buffer $(\mathrm{pH} 6.5)$ at a flow rate of $50 \mathrm{ml} / \mathrm{h}$, and $250 \mu \mathrm{l}$ fractions were collected and stored at $-20{ }^{\circ} \mathrm{C}$.

Unless otherwise stated, results shown for the separation of the above fluids are representative of at least three column runs of each pool.

\section{Distribution of IGFBP-3 in column fractions}

Five microlitres synovial fluid, $2.5 \mu \mathrm{l}$ serum or $50 \mu \mathrm{l}$ column fractions were boiled with SDS sample buffer before the samples were loaded onto a $12 \cdot 5 \%$ polyacrylamide gel. Proteins were separated by electrophoresis at $70 \mathrm{~mA}$ overnight and then transferred on to Hybond $\mathrm{C}$ membranes for $4 \mathrm{~h}$ at $0 \cdot 8 \mathrm{~A}$ constant current. Intact and fragmented (proteolytically modified) forms of IGFBP-3 were visualised by western immunoblotting. The membranes were blocked in Tris-buffered saline and 3\% non-fat milk before incubation with a specific polyclonal antibody for IGFBP-3 (SCH 2/6, which recognises intact IGFBP-3, the major 30, 21 and $15 \mathrm{kDa}$ fragments, and other minor fragments) at 1:10 000 at room temperature overnight. The membranes were then washed in Trisbuffered saline to remove unbound antibody before incubation with an anti-rabbit antibody conjugated to peroxidase (1:10 000) for $1 \mathrm{~h}$ at room temperature. Binding of the peroxidase-labelled antibody was visualised using enhanced chemiluminesence with an ECL detection system (Amersham, Amersham, Bucks, UK) and exposure to X-ray film.

In addition, $50 \mu \mathrm{l}$ aliquots of column fractions were assayed for IGFBP-3 by radioimmunoassay as described previously (Cheetham et al. 1994).

\section{Distribution of IGF-I in column fractions}

Column fractions were concentrated tenfold and IGF-I was measured by radioimmunoassay (as described by Helle et al. 1998) after acid-ethanol extraction to remove binding proteins (Bowsher et al. 1991). To minimise the effect of any remaining residual binding proteins, $10 \mathrm{ng}$ IGF-II was added to each tube.

\section{Acid-labile subunit assay}

ALS measurements in intact samples were performed using an ELISA kit for total ALS obtained from DSL (Webster, TX, USA).

\section{Assay for IGFBP-3 proteolytic activity}

Intact (non-separated) samples and column fractions were assayed for their ability to fragment radiolabelled (iodine125) recombinant ngIGFBP-3 ( ${ }^{125}$ I-ngIGFBP-3, iodinated using a chloramine $\mathrm{T}$ method) according to the method of Lamson et al. (1991). Briefly, $5 \mu$ l each intact sample (in a total volume of $50 \mu \mathrm{l}$ in $0.05 \mathrm{M}$ phosphate buffer $\mathrm{pH}$ 6.5) and $50 \mu \mathrm{l}$ each column fraction were incubated with 15000 c.p.m. ${ }^{125} \mathrm{I}$-ngIGFBP-3 for up to $24 \mathrm{~h}$ at $37^{\circ} \mathrm{C}$. The assay was stopped by boiling $20 \mu \mathrm{l}$ aliquots of the incubation volume with SDS loading buffer before loading onto a $12.5 \%$ SDS polyacrylamide gel, which was run overnight at $30 \mathrm{~mA}$. Fragmentation of the labelled substrate was visualised by fixing and drying the gels and exposing them to X-ray film at $-70{ }^{\circ} \mathrm{C}$ for $2-3$ days. Two areas of IGFBP-3 proteolytic activity were identified in fractions from the size separation of serum or synovial fluid: one area contained molecules of approximately $200 \mathrm{kDa}$ (approximate fraction numbers 16/17, sizes are according to column calibration); the other contained molecules of approximately $50-60 \mathrm{kDa}$ (approximate fraction numbers 25/26). These have been termed the high-molecular mass (MM) area of IGFBP-3 protease activity and the low-MM area of IGFBP-3 protease activity respectively. In addition, fractions containing molecules of approximately $150 \mathrm{kDa}$ (approximate fraction numbers 22/23) showed no proteolytic activity against IGFBP-3.

\section{Inhibition of IGFBP-3 proteolytic activity in intact (non-separated) fluids and column fractions}

Five or 10 microlitre aliquots of intact fluids or $50 \mu \mathrm{l} \mathrm{high-}$ and low-MM areas of IGFBP-3 proteolytic activity from 
each fluid were mixed with 5 or $10 \mu \mathrm{l}$ intact normal adult serum or RASynF and then incubated in a protease assay as described above. In addition, protease assays were performed on 5 or $10 \mu \mathrm{l}$ intact NSynF or serum from pregnant women, or 25 or $50 \mu$ of the high- and low-MM areas of IGFBP-3 protease activity from each fluid, mixed with 25 or $50 \mu 1150 \mathrm{kDa}$ fractions from the separation of normal adult serum and RASynF.

Inhibition of IGFBP-3 proteolytic activity in column fractions by excess IGFBP-3

Fifty microlitres high- and low-MM areas of IGFBP-3 protease activity from normal adult serum were mixed with 500 and $150 \mathrm{ng}$ recombinant glycosylated IGFBP3 (gIGFBP-3), or 200, 100 and $50 \mathrm{ng}$ recombinant ngIGFBP-3 and incubated in a protease assay as described above.

\section{Results}

IGFBP-3 distribution and status in synovial fluid

The size separation of NSynF, OASynF and RASynF allows for a more detailed description of the changes in the IGF axis seen in the fluids from the arthritic joints. Figure 1 and Table 1 demonstrate that, in addition to the increases in IGFBP-3 doublet seen in RASynF and OASynF, there was a change in the distribution of the binding protein. In NSynF (Fig. 1A) most of the IGFBP-3 is in a proteolytically modified or fragmented form and $92 \%$ was present in fractions that contained molecules of about $50 \mathrm{kDa}$, suggesting it was predominantly present in a binary complex with IGFs-I or -II (Baxter \& Martin 1989a). In both RASynF (Fig. 1B) and OASynF (Fig. 1C) a large proportion of the IGFBP-3 is found in a nonproteolysed form. In these fluids $65 \%$ and $62 \%$ of IGFBP-3 respectively are in fractions containing molecules of about $150 \mathrm{kDa}$, with only $34 \%$ and $37 \%$ being found in the binary complex. In order for IGFBP-3 to form a ternary complex of $150 \mathrm{kDa}$, it must be bound to IGF-I or II and the ALS (Baxter \& Martin 1989b).

Figure 2A further shows this shift in the IGFBP-3 distribution profile (quantified by radioimmunoassay) in fractions obtained from the size-separation of OASynF and RASynF. More IGFBP-3 is in the $150 \mathrm{kDa}$ fractions in OASynF and RASynF than in NSynF.

\section{IGF-I distribution and ALS concentrations in synovial fluid}

Figure 2B reveals a similar change in distribution of IGF-I (quantified by radioimmunoassay) in OASynF and RASynF. Whereas in the NSynF there is little IGF-I in the $150 \mathrm{kDa}$ fractions, in RASynF and OASynF there is a large increase in IGF-I. The profiles for RASynF and

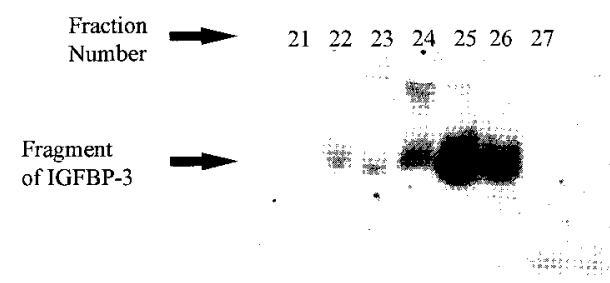

A

$150 \mathrm{kDa} \quad 50 \mathrm{kDa}$

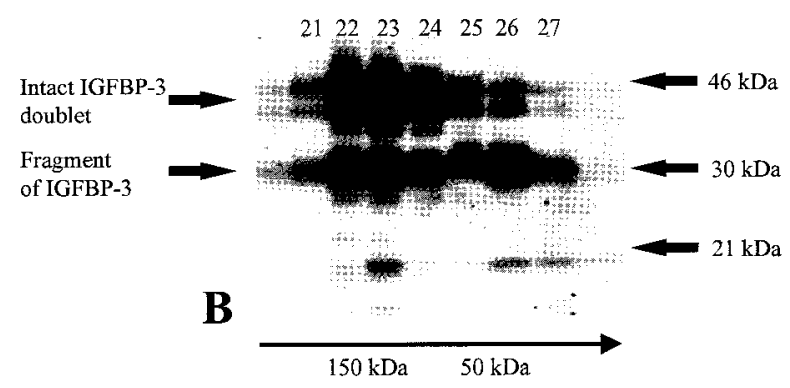

$\begin{array}{lllllll}1 & 22 & 23 & 24 & 25 & 26 & 27\end{array}$

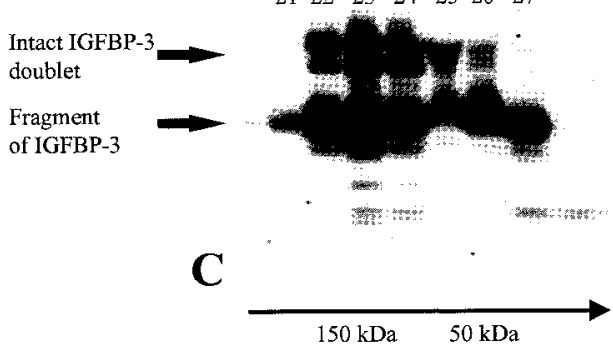

Figure 1 Western immunoblot showing IGFBP-3 doublet and fragments in size-separated column fractions from NSynF (A), RASynF (B) and OASynF (C). Column fraction numbers and approximate sizes of molecules eluted in the fractions are indicated. The molecular masses of the bands are indicated at the side of the panel.

OASynF also resemble the profile seen for IGF-I distribution in normal adult serum (results not shown).

There was a significant increase in the concentrations of ALS in RASynF and OASynF compared with NSynF $(P$ values of 0.036 and 0.044 respectively, Student's $t$-test;

Table 1 Amounts of IGFBP-3 in synovial fluid size-separation column fractions found in a ternary complex (approximately $150 \mathrm{kDa}$ ) or a binary complex (approximately $50 \mathrm{kDa}$ ), expressed as a percentage of the total IGFBP-3 levels measured in these fractions

IGFBP-3 (\% of total) present in

\begin{tabular}{lrr}
\cline { 2 - 3 } NSynF & $7 \cdot 7$ & $92 \cdot 3$ \\
RASynF & $65 \cdot 4$ & $34 \cdot 6$ \\
OASynF & $62 \cdot 5$ & $37 \cdot 5$ \\
\hline
\end{tabular}



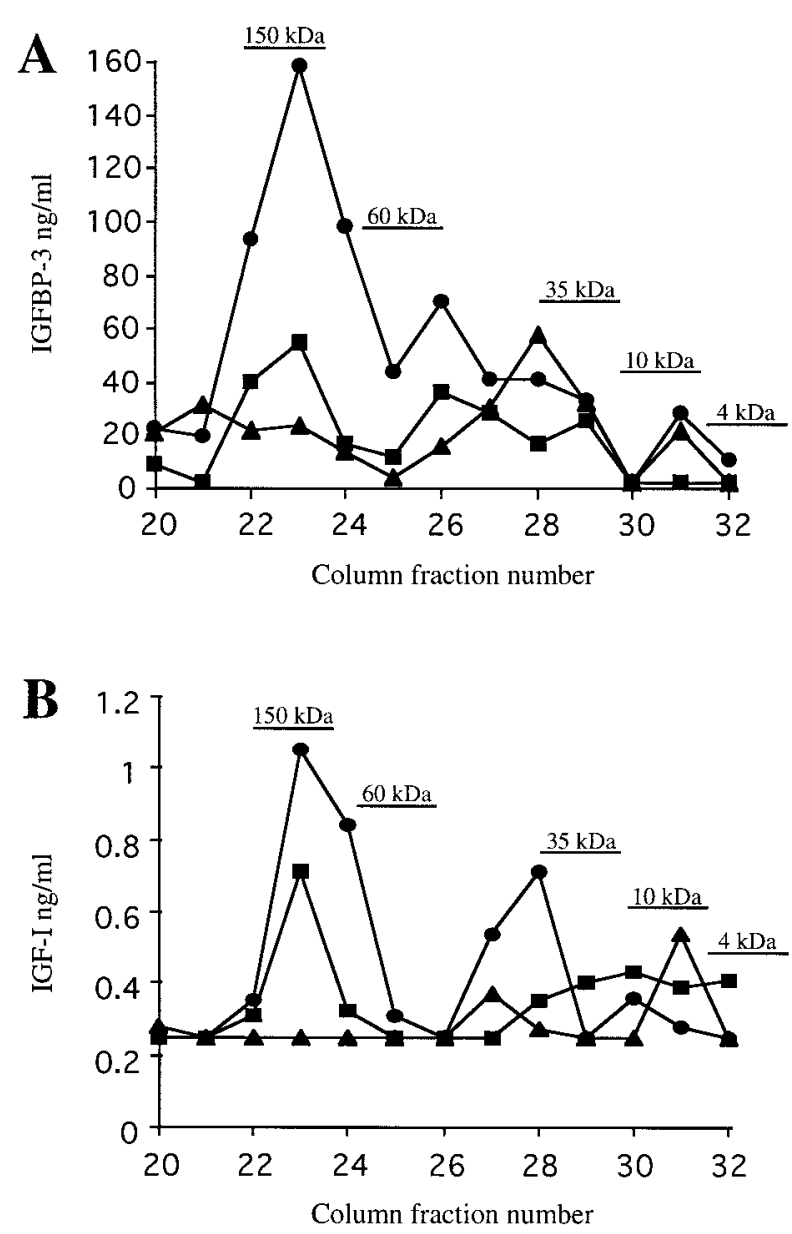

Figure 2 Distribution of IGFBP-3 (A) and IGF-I (B) quantified by radioimmunoassay, in representative samples of size-separated column fractions from $\operatorname{NSynF}(\boldsymbol{\Delta}), \operatorname{RASynF}(\boldsymbol{\bullet})$ and $\mathrm{OASynF}(\boldsymbol{\square})$ IGFBP-3 and IGF-I concentrations are expressed as $\mathrm{ng} / \mathrm{ml}$ of fraction and represent the concentration of IGFBP-3 or IGF-I in approximately $100 \mu \mathrm{l}$ of each synovial fluid. Approximate sizes of molecules eluted in the fractions are indicated.

Fig. 3). This supports the idea that the increase in both IGF-I and IGFBP-3 seen in RASynF and OASynF is a reflection of an increase in the ternary complex.

In vitro IGFBP-3 protease activity in serum and synovial fluid

In addition to an increase in intact IGFBP-3, there was a decrease in in vitro proteolysis by both RASynF and OASynF. In vitro protease assays with ${ }^{125}$ I-ngIGFBP-3 as substrate are commonly used to visualise the relative amounts of IGFBP-3 protease activity in physiological fluids; intact (non-proteolysed) ${ }^{125} \mathrm{I}$-ngIGFBP-3 is seen as a distinct band at $29 \mathrm{kDa}$, whereas fragments are apparent as lower-MM bands. Normal adult serum had very little specific activity, as demonstrated by the distinct band at

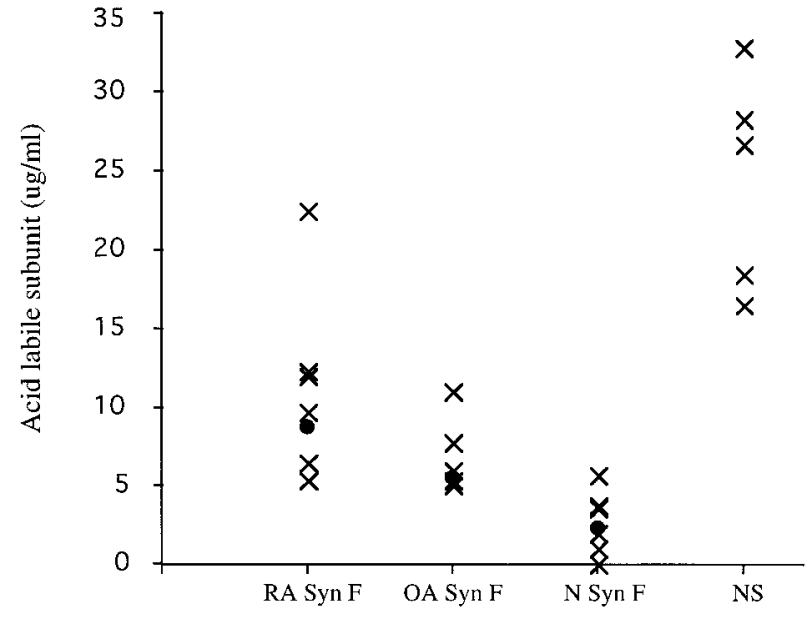

Figure 3 ALS concentrations in individual $(\times)$ or pool samples $(\mathbf{O})$ in RASynF, OASynF, NSynF and normal adult serum. Each point represents the mean of three replicates determined by ELISA. Statistical significance ( $t$-test): $P=0 \cdot 036$, RASynF compared with NSynF; $P=0 \cdot 044$, OASynF compared with NSynF; no significant difference between RASynF and OASynF.

$29 \mathrm{kDa}$ and the absence of lower-MM fragments (Fig. 4, lane 1). In contrast, serum from pregnant women had considerable activity; there was almost no intact ngIGFBP-3 at $29 \mathrm{kDa}$, but a clear band of fragmented IGFBP-3 at $21 \mathrm{kDa}$ (Fig. 4, lane 2). RASynF was comparable to normal adult serum (Fig. 4, lane 3), whereas OASynF (Fig. 4, lane 4) had more activity than normal adult serum, though some substrate remained intact. In NSynF (Fig. 4, lane 5) almost all the ngIGFBP-3 has been fragmented, giving a pattern comparable to that of serum from pregnant women.

In vitro IGFBP-3 protease activity in column fractions from the size-separation of serum and synovial fluid

Fractionation of normal adult serum (and serum from pregnant women - results not shown) by molecular mass

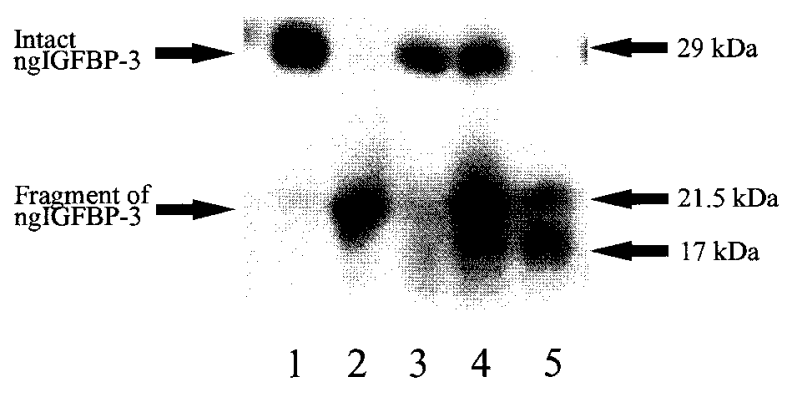

Figure 4 Autoradiograph of IGFBP-3 protease assays. Incubation of $5 \mu \mathrm{l}$ normal adult serum (lane 1), serum from pregnant women (lane 2), RASynF (lane 3), OASynF (lane 4) and NSynF (lane 5) with ${ }^{125}$ I-ngIGFBP-3 for $24 \mathrm{~h}$ at $37^{\circ} \mathrm{C}$. Molecular masses of the bands are indicated at the side. 


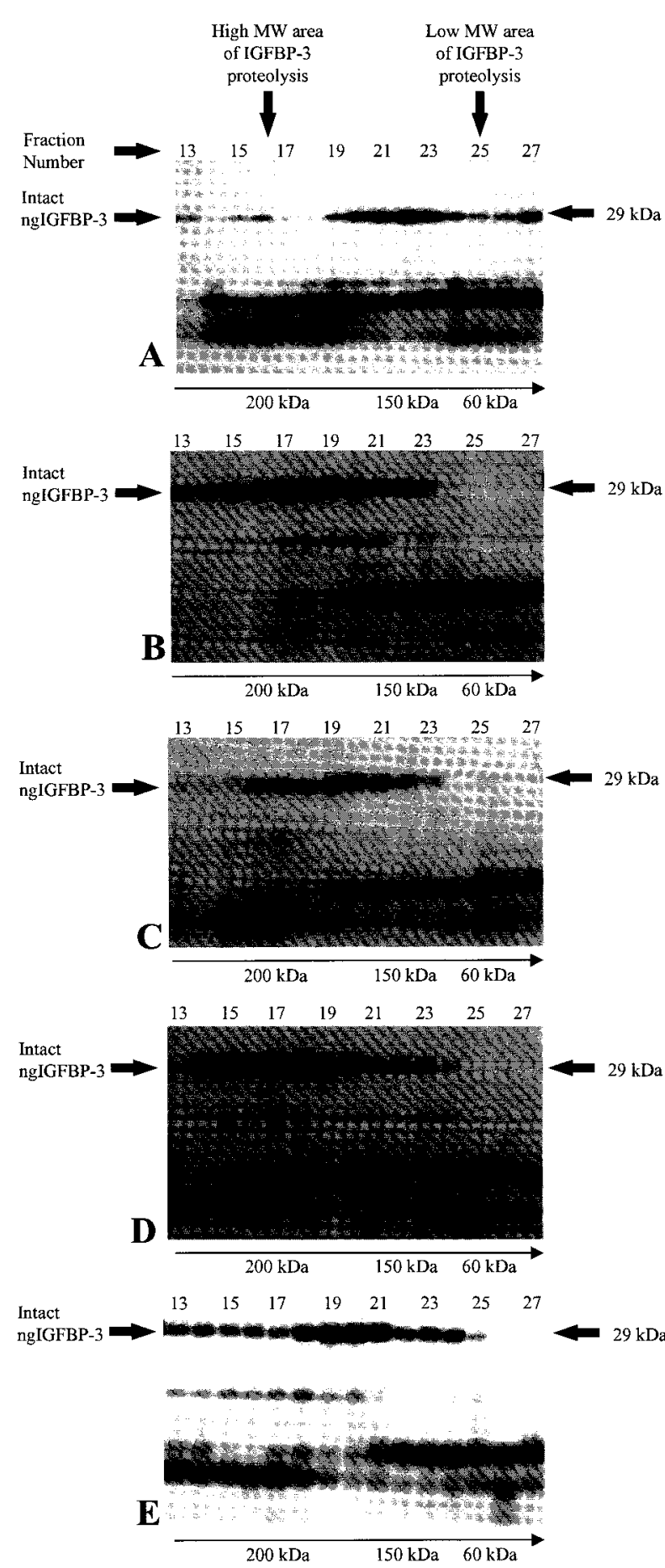

Figure 5 Autoradiograph of IGFBP-3 protease assays. Incubation of size-separated column fractions from normal adult serum (A), NSynF (B), RASynF (C), OASynF (D) and OASynF with high-MM area of activity (E), with ${ }^{125}$ I-nglGFBP-3 for $24 \mathrm{~h}$ at $37^{\circ} \mathrm{C}$. Column fraction number, areas of IGFBP-3 proteolytic activity and approximate sizes of molecules in the fractions are indicated. $\mathrm{MW}$, molecular weight/mass. on a gel filtration column and incubation of the fractions with ${ }^{125}$ I-ngIGFBP-3 revealed a high- and a low-MM area in which IGFBP-3 was proteolysed (Fig. 5A). After molecular mass size-separation of NSynF (Fig. 5B), there was distinct proteolytic activity in fractions of about $60 \mathrm{kDa}$, comparable to the low-MM area of activity seen after separation of both normal adult serum and serum from pregnant women. The high-MM area of activity seen after separation of serum was absent, however. The separation of OASynF also revealed a distinct area of activity in fractions of about $60 \mathrm{kDa}$ (Fig. 5D); however, the presence of the high-MM area varied between patients: in some this activity was absent (Fig. 5D), whereas in others it was apparent (Fig. 5E). Both the highand low-MM areas of activity were apparent after the separation of RASynF (Fig. 5C), despite the lack of IGFBP-3 proteolysis in the intact, non-separated sample (Fig. 4, lane 3).

Inhibition of in vitro IGFBP-3 protease activity in intact (non-separated) and size separated serum and synovial fluid

The presence of IGFBP-3 protease activity in normal adult serum and RASynF after size separation, but not in the intact sample, suggested the presence of inhibitors that were separated from the activity during the chromatographic process. Figures 6 and 7 demonstrate the inhibitory activity in both normal adult serum and RASynF. Figure 6 shows a decrease in IGFBP-3 protease activity in NSynF (Fig. 6A), and a further decrease in IGFBP-3 proteolysis in OASynF (Fig. 6B) when normal adult serum or RASynF was added to the assay: the intact substrate band increased and fragment bands decreased. However, when normal adult serum or RASynF was incubated with serum from pregnant women (Fig. 6C), this inhibition was not achieved, suggesting that serum from pregnant women is not affected by, or has the ability to overcome this inhibition. When the high- and low-MM areas of activity obtained from the separation of synovial fluids were incubated with either intact normal adult serum (Fig. 7A) or intact RASynF (Fig. 7B), almost all the activity was inhibited. This is evident in the increase in the amount of IGFBP-3 substrate remaining as an intact non-proteolysed band and the decrease in the lower-MM fragments compared with the high- and low-MM areas of activity incubated with buffer alone (Fig. 7C). This pattern of inhibition could not be achieved by incubating the same fractions with intact OASynF or intact NSynF.

In order to demonstrate further the presence of inhibitory activity, $150 \mathrm{kDa}$ fractions from RASynF and normal adult serum separations, which were shown to lack protease activity against IGFBP-3, were used. These fractions were incubated with intact $\mathrm{NSynF}$ and serum from pregnant women, and with the high- and low-MM areas obtained from the separation of all three synovial fluids. Figure 8 shows the ability of these $150 \mathrm{kDa}$ fractions to 


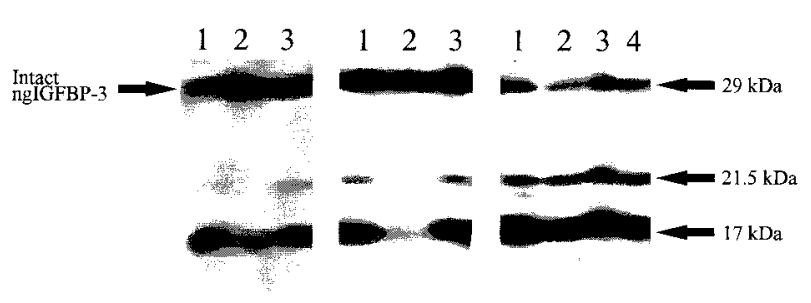

A $\quad$ B $\quad$ C

Figure 6 Autoradiograph of IGFBP-3 protease assays. Incubation of $5 \mu \mathrm{l}$ intact NSynF (A), OASynF (B) and serum from pregnant women (C) with assay buffer alone (lane 1) or $5 \mu$ intact RASynF (lane 2), normal adult serum (lane 3) or OASynF (lane 4).

inhibit IGFBP-3 proteolysis in NSynF (Fig. 8A), evident as an increase in intact substrate. Conversely, these $150 \mathrm{kDa}$ fractions could not prevent protease activity in serum from pregnant women (Fig. 8B). Figure 8 also shows the inhibitory effect of these fractions from normal adult serum and RASynF on the high- and low-MM IGFBP-3 protease activity areas from RASynF (Fig. 8C, D), OASynF (Fig. 8E, F) and NSynF (Fig. 8G). The first lane in each group is the high- or low-MM area of activity incubated with ${ }^{125}$ I-ngIGFBP-3 alone, the second lane is the high- or low-MM area of activity incubated with ${ }^{125}$ I-ngIGFBP-3 and $150 \mathrm{kDa}$ fractions from RASynF separation, and the third lane is the area of activity incubated with substrate and the $150 \mathrm{kDa}$ fractions from the separation of normal adult serum. In all cases there is considerably more intact ${ }^{125}$ I-ngIGFBP-3 in the presence of the $150 \mathrm{kDa}$ fractions and a change in the fragmentation pattern, shown by a decrease in smaller-MM fragments present. Interestingly, inhibition of non-fractionated NSynF or low-MM activity from NSynF by the $150 \mathrm{kDa}$ fractions from RASynF or normal adult serum resulted in slightly different fragment patterns. Intact ${ }^{125} \mathrm{I}$ ngIGFBP-3 was increased in both protease assays, but the $21.5 \mathrm{kDa}$ fragment increased only in the low-MM activity area from NSynF. This could suggest the presence of multiple proteases in NSynF, with different susceptibilities to inhibition, as the protease cleaving this $21.5 \mathrm{kDa}$ fragment in non-fractionated NSynF is not inhibited by the $150 \mathrm{kDa}$ fractions.

Excess recombinant non-radiolabelled gIGFBP-3 and ngIGFBP-3 were incubated with the high- and low-MM areas of IGFBP-3 protease activity from the separation of normal adult serum, but did not cause inhibition of

${ }^{125}$ I-ngIGFBP-3 proteolysis (Fig. 9). These results indicate that the inhibitory effects of intact normal adult serum, RASynF and their $150 \mathrm{kDa}$ fractions were not due to saturation of the IGFBP-3 protease activity by IGFBP-3 present in these samples. In addition, the actual amount of IGFBP-3 added to protease assays by using normal adult serum and RASynF samples would be much less than those used in this experiment.

\section{Discussion}

This study has shown that, along with the previously reported increases in IGFs-I and -II and IGFBP-3 in synovial fluid from patients with RA or OA, there is also a shift in the distribution of these molecules compared with that in NSynF. We have demonstrated that ALS is increased and that IGFs-I and -II and IGFBP-3 are mostly complexed with the ALS in a $150 \mathrm{kDa}$ ternary complex (which would normally be too large to cross the vascular membrane barrier; Baxter \& Martin 1989b), whereas a binary complex of approximately $50 \mathrm{kDa}$ predominates in NSynF. IGF-I bound in a high-affinity $150 \mathrm{kDa}$ complex would probably be excluded from the cartilage matrix, preventing IGF-I from interacting with its receptor on chondrocytes.

A change in the components of the IGFBP-3 proteolytic activity system in RA and OA was also apparent. In NSynF endogenous IGFBP-3 was proteolytically modified to smaller-MM fragments, and the addition of radiolabelled ngIGFBP-3 to NSynF also resulted in

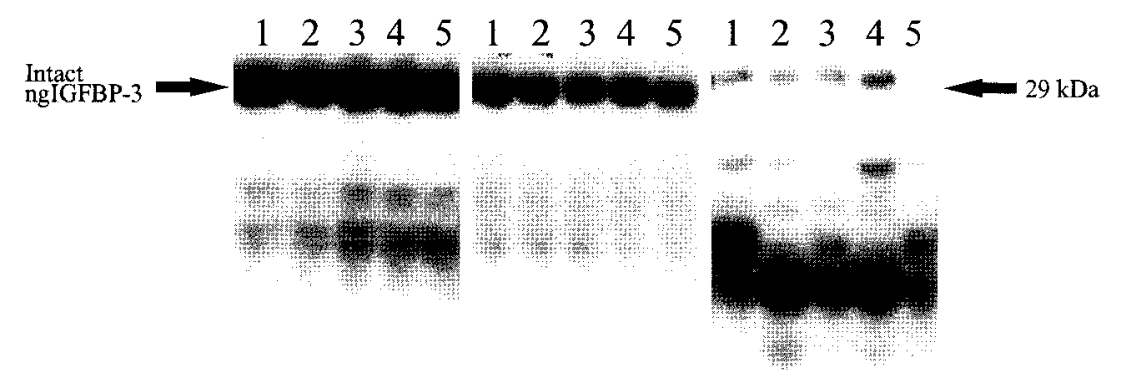

\section{A $\quad$ B $\quad$ C}

Figure 7 Autoradiograph of IGFBP-3 protease assays. Incubation of $50 \mu$ l low-MM areas of IGFBP-3 protease activity from NSynF (lane 1), RASynF (lane 3) and OASynF (lane 5), or $50 \mu$ high-MM areas of IGFBP-3 protease activity from RASynF (lane 2) and OASynF (lane 4) with $5 \mu$ intact normal adult serum (A), intact RASynF (B) or assay buffer alone (C). 


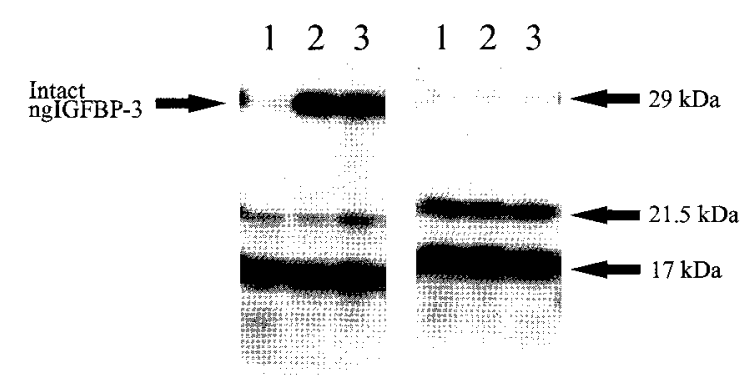

A $\quad$ B

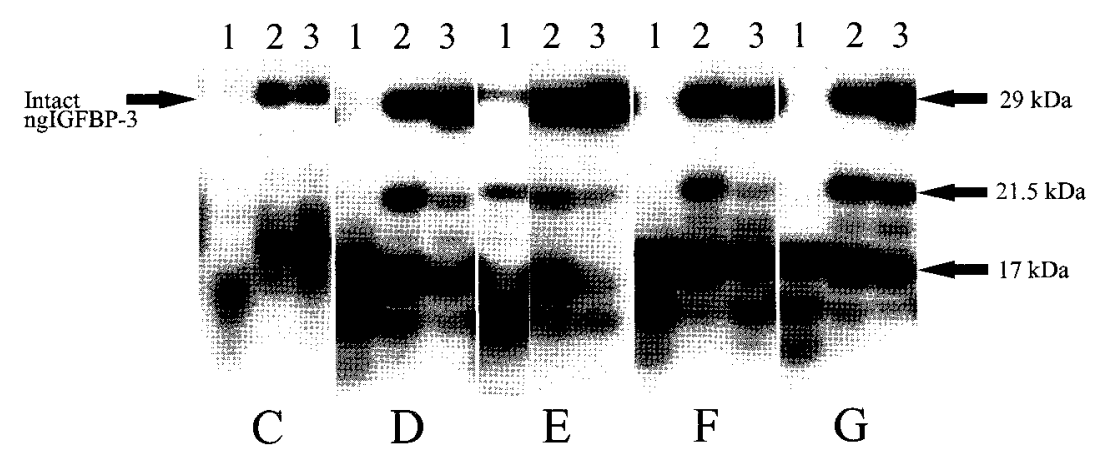

Figure 8 Autoradiograph of IGFBP-3 protease assays. Incubation of $5 \mu$ lintact NSynF (A) or serum from pregnant women (B) with assay buffer alone (lane 1), or $50 \mu \mathrm{l}$ fractions of $150 \mathrm{kDa}$ from the size-separation of RASynF (lane 2) and normal adult serum (lane 3). Incubation of $25 \mu$ l high-MM areas of IGFBP-3 protease activity from RASynF (C) and OASynF (E), or $25 \mu$ l low-MM areas of IGFBP-3 protease activity from RASynF (D), OASynF (F) and NSynF (G) with assay buffer alone (lane 1) or $25 \mu \mathrm{l}$ fractions of $150 \mathrm{kDa}$ from the size separation of RASynF (lane 2) and normal adult serum (lane 3).

cleavage of the binding protein. In RASynF, and to some extent in OASynF, there was a lack of this protease activity, which was surprising in the context of the general increase in catalytic enzymes that is characteristic of RA and OA joints (Dean et al. 1989, Mort et al. 1993). However, we have shown that size-separation of the system components identifies proteases present in RASynF and OASynF, and in NSynF capable of activity against IGFBP-3. This clearly demonstrates that the lack of IGFBP-3 proteolysis in non-separated RASynF and OASynF is not due to the loss of a protease or its activity, but could suggest the presence of inhibitors that protect IGFBP-3 from cleavage. The net result is a reduction in IGF bioavailability and therefore a reduction in anabolic stimulus.

The argument could also be made from these data that, to a large degree, the disruption in the IGF system is due to an increased influx of proteins to the joint space/ synovial fluid from serum. A number of studies have reported an increase in IGFs-I and -II and IGFBP-3, and suggested the increased concentrations may be due to an increase in production and a decrease in clearance by proteolysis of the binding protein that associates with IGF, increasing its half-life and therefore its concentration (Fernihough et al. 1996, Matsumoto et al. 1996, Tavera et al. 1996, Neidel et al. 1997). However, the inflammatory response that is characteristic of RA disease and which may occur at certain stages in OA disease (Pelletier et al. 1993) could also be responsible for these increased concentrations. Inflammation alters the vascular membrane permeability (Roitt et al. 1989) and, although it has been reported that there is no increase in vascularization of synovium in RA (Stevens et al. 1991), the change in vascular membrane permeability could allow molecules that are normally size-excluded to gain access to the joint space. The demonstrated increase in ALS and associated increase in $150 \mathrm{kDa}$ ternary complex provide evidence for this theory, along with the appearance of a high-MM area of IGFBP-3 proteolysis (above $200 \mathrm{kDa}$ ) in RASynF and in some OASynF. This is normally only identifiable in normal adult serum or serum from pregnant women (Bang \& Fielder 1997, Maile et al. 1998) and was not present in 

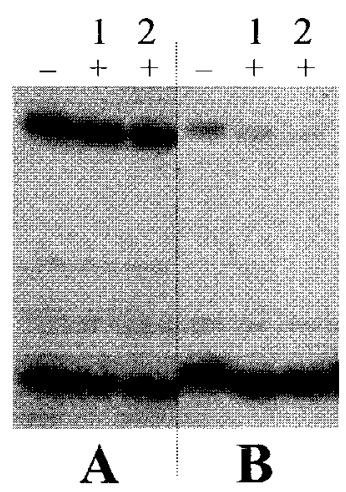

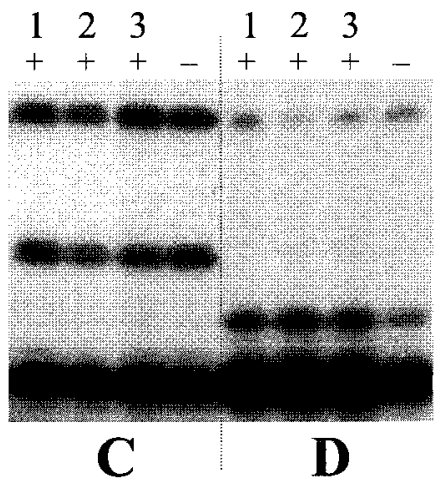

Figure 9 Autoradiograph of IGFBP-3 protease assays. High- (A and C) and low- (B and D) MM areas of protease activity from normal adult serum incubated alone ( - ) or with (+): $500 \mathrm{ng}$ recombinant gIGFBP-3 (A and B, lane 1), 150 ng recombinant gIGFBP-3 (A and $B$, lane 2), $200 \mathrm{ng}$ recombinant nglGFBP-3 (C and D, lane 1), $100 \mathrm{ng}$ nglGFBP-3 (C and D, lane 2 ) or $50 \mathrm{ng}$ nglGFBP-3 (C and $\mathrm{D}$, lane 3).

NSynF. In addition, the absence of high-MM activity in some separated OASynF samples may reflect a lower level of inflammation in these patients. It has been reported that molecules as large as $\alpha_{2}$-macroglobulin $(725 \mathrm{kDa})$ are present in RASynF and OASynF (Virca et al. 1984), again suggesting a massive disruption of the joint space and synovial fluid constituents by an influx of serum proteins. Fernihough et al. (1996) also found a strong correlation between synovial fluid IGFs-I and -II and IGFBP-3 concentrations and serum C-reactive protein (CRP) concentrations in RA. CRP reflects cytokine activity in the body, and the involvement of the immune system/general inflammation in disease. Therefore increases in CRP concentrations could reflect an increase in vascular permeability. This would allow more serum proteins, including IGF system components, to enter the joint space and so increase the concentrations of IGFs-I and -II and IGFBP-3 in synovial fluid.

We have demonstrated that the proteases responsible for IGFBP-3 proteolysis in synovial fluid are predominantly the same as those present in serum in terms of proteolytic fragment patterns and size distribution. However, in normal physiology, serum would probably not be the source of these enzymes and their regulators, suggesting that IGFBP-3 proteolysis is controlled locally within the joint space in normal tissue. The lack of IGFBP-3 protease activity in intact normal adult serum and RASynF, and the decrease in OASynF, imply the presence of inhibitors or a resistance of IGFBP-3 to proteolysis in these samples. This was not apparent in NSynF and indicates a significant disturbance to the IGFBP-3 proteolysis system in RA and OA. We have also isolated this inhibitory ability in intact RASynF and normal adult serum, and localised it to the $150 \mathrm{kDa}$ area from the size separation of these two fluids. This corresponds exactly to the ternary complex of IGFs-I and -II, IGFBP-3 and ALS.
The identity of the proteases involved in IGFBP-3 proteolysis remains unclear. A number of enzymes have been shown to be capable of cleaving IGFBP-3 in vitro, including metalloproteinases (Kubler et al. 1998), plasmin (Booth et al. 1996) and cathepsin D (Claussen et al. 1997), but there is little evidence that these enzymes are the active components of the IGFBP-3 proteolysis system in vivo. We have previously used known inhibitors such as EDTA, aprotinin, and tissue inhibitor of metalloproteinase- 1 on the proteolytic activity areas isolated from normal adult serum, and these suggest a metal-ion-dependent serine protease is involved (Maile et al. 1998). It could also be possible that a cascade of enzymes is involved. The pregnancy-associated plasma protein-A has very recently been identified as an IGFdependent protease of IGFBP-4 (Lawrence et al. 1999); however, IGF-independent protease activity against IGFBP-4 has also been isolated and this could imply that protease activity directed against any of the IGFBPs is complex, consisting of multiple components.

The loss of IGFBP-3 proteolysis in RASynF and OASynF demonstrated in this study could also be caused by infiltration of inhibitor from the circulation. However, the nature of this inhibition also remains in question. Whether the inhibition of IGFBP-3 proteolysis is achieved by the interaction of enzymes and their constitutive inhibitors (e.g. $\alpha-2$ antiplasmin complexing with plasmin) or by the association of IGFBP-3 with a distinct inhibitor, or whether IGFBP-3 is conformationally protected from proteolysis is under investigation. It is increasingly evident that IGFBP-3 is able to associate with molecules outside the IGF system (Campbell et al. 1998), and this may regulate IGFBP-3 protection from, or susceptibility to, proteolysis (Durham et al. 1999). Inhibition of IGFBP-3 proteolysis by $150 \mathrm{kDa}$ column fractions from RASynF and normal adult serum could suggest that there is an inhibitor that is associated with the IGFBP-3 in the $150 \mathrm{kDa}$ complex. This inhibitor could also bind to added exogenous ngIGFBP-3. Alternatively, it could also be possible that enzyme inhibitors are co-purified in the $150 \mathrm{kDa}$ area fractions.

The inhibitory ability of intact RASynF and $150 \mathrm{kDa}$ column fractions on the high- and low-MM areas of IGFBP-3 proteolysis and intact NSynF could not be achieved on incubation with serum from pregnant women. This suggests that there is a change in the IGFBP-3 proteolytic activity system in serum from pregnant women, so that it can overcome this inhibition. In this serum, almost all the IGFBP-3 is proteolytically modified; indeed, the first observations of IGFBP-3 proteolysis were made in this fluid. The proteolysis is believed to occur by some override mechanism in the IGFBP-3 proteolytic system, whereby enzymes cleaving IGFBP-3 are perpetually active and/or the IGFBP-3 is not protected by an enzyme inhibitor or a certain conformation. 
There is a large amount of evidence to suggest that the IGF system is disrupted in RA and OA, and previous studies propose that the increased concentrations of IGF system components (IGFs-I and -II and IGFBPs-2-4) in synovial fluid from patients with RA or OA are the result of increased production of these molecules by joint tissues. Indeed, there is in vitro evidence to support this (Dequeker et al. 1993, Yateman et al. 1993, Matsumoto et al. 1994, Dore et al. 1995, Keyszer et al. 1995). It is possible that these local changes in cell function could be masked by the massive infiltration of serum proteins proposed in this study. It would therefore be difficult to use synovial fluid from patients with RA or OA as the sole indication of local tissue changes in the IGF system in RA and OA, although these will be an underlying and integral part of the disease process.

In conclusion, these data have identified that the availability of IGF within the normal joint capsule is probably controlled by proteolysis of binding proteins. This system is likely to be regulated locally, and the observed disruption by serum components greatly perturbs the IGF axis. The identity of the protease or proteases responsible for cleaving IGFBP-3 remain unknown, but the localisation and regulation of identifiable IGFBP-3 protease activity may provide future clues as to the identity of this enzyme system. In addition, as IGFs-I and -II are considered important anabolic stimuli for cartilage matrix production (McQuillan et al. 1986b, Vetter et al. 1986), the loss of these stimuli shown by our data must have a great impact on disease progression in RA and OA.

\section{Acknowledgements}

The research in this paper was supported by the Arthritis Research Campaign. J K Fernihough and M E J Billingham were supported by Arthromics PLC.

\section{References}

Altman R, Asch E, Bloch D, Bole G, Borenstein D, Brandt K, Christy W, Cooke TD, Greenwald R, Hochberg M et al. 1986 Development of criteria for the classification and reporting of osteoarthritis: classification of osteoarthritis of the knee. Arthritis and Rheumatism 29 1039-1049.

Arnett FC, Edworthy SM, Bloch DA, McShane DJ, Fries JF, Cooper NS, Healey LA, Kaplan SR, Liang MH, Luthra HS et al. 1988 The American Rheumatism Association 1987 revised criteria for the classification of rheumatoid arthritis. Arthritis and Rheumatism 31 315-324.

Bang P \& Fielder PJ 1997 Human pregnancy serum contains at least two distinct proteolytic activities with the ability to degrade insulinlike growth factor binding protein-3. Endocrinology 138 3912-3917.

Baxter RC \& Martin JL 1989a Binding proteins for the insulin-like growth factors - structure, regulation and function. Progress in Growth Factor Research 1 49-68.
Baxter RC \& Martin JL 19896 Structure of the Mr 140000 growth hormone-dependent insulin-like growth factor binding proteincomplex: determination by reconstitution and affinity labelling. PNAS 86 6898-6902.

Booth BA, Boes M \& Bar RS 1996 IGFBP-3 proteolysis by plasmin, thrombin, serum: heparin binding, IGF binding, and structure of fragments. American Journal of Physiology 271 E465-E470.

Bowsher RR, Lee W-H, Apathy JM, O'Brien PJ, Ferguson AL \& Henry DP 1991 Measurement of insulin-like growth factor-II in physiological fluids and tissues. An improved extraction procedure and radioimmunoassay for lumen and rat fluids. Endocrinology 128 805-814.

Campbell PG, Durham SK, Suwanichkul A, Hayes JD \& Powell DR 1998 Plasminogen binds the heparin-binding domain of insulin-like growth factor binding protein-3. American Journal of Physiology 275 E321-E331

Cheetham TD, Taylor A, Holly JMP, Clayton K, Cwyfan-Hughes SC \& Dunger DB 1994 The effects of recombinant human insulinlike growth factor-I (IGF-I) administration on the levels of IGF-I, IGF-II and IGF binding proteins in adolescents with insulin-dependent diabetes mellitus. Journal of Endocrinology 142 367-374.

Claussen M, Kubler B, Wendland M, Neifer K, Schmidt B, Zapf J \& Braulke T 1997 Proteolysis of insulin-like growth factors (IGF) and IGF binding proteins by cathepsin D. Endocrinology 138 3797-3803.

Dean DD, Martel-Pelletier J, Pelletier JP, Howell DS \& Woessner JF Jr 1989 Evidence for metalloproteinase and metalloproteinase inhibitor imbalance in human osteoarthritic cartilage. Journal of Clinical Investigation 84 678-685.

De Keyser F, Elewaut D, Vermeersch J, De Wever N, Cuvelier C \& Veys EM 1995 The role of T cells in rheumatoid arthritis. Clinical Rheumatology 14 (suppl 2) 5-9.

Dequeker J, Mohan R, Finkelman RD, Aerssens J \& Baylink DJ 1993 Generalised osteoarthritis associated with increased insulin-like growth factor types I and II and transforming growth factor beta in cortical bone from the iliac crest. Possible mechanism of increase bone density and protection against osteoporosis. Arthritis and Rheumatism 36 1702-1708.

Dore S, Pelletier JP, DiBattista JA, Tardif G, Brazeau P \& MartelPelletier J 1994 Human osteoarthritic chondrocytes possess an increased number of insulin-like growth factor 1 binding sites but are unresponsive to its stimulation. Arthritis and Rheumatism 37 253-263.

Dore S, Abribat T, Rousseau N, Brazeau P, Tardif G, DiBattista JA, Cloutier JM, Pelletier JP \& Martel-Pelletier J 1995 Increased insulin-like growth factor-I production by human osteoarthritic chondrocytes is not dependent on growth hormone action. Arthritis and Rheumatism 38 413-419.

Durham SK, Suwanichkul A, Hayes JD, Herington AC, Powell DR \& Campbell PG 1999 The heparin binding domain of insulin-like growth factor binding protein (IGFBP)-3 increases susceptibility of IGFBP-3 to proteolysis. Hormone and Metabolic Research 31 216-225.

Fassbender HG 1994 Inflammatory reactions in arthritis. In The Handbook of Immunopharmacology: Immunopharmacology of Joints and Connective Tissue, pp 84-96. Eds ME Davies \& JT Dingle. London: Academic Press.

Fernihough JK, Billingham MEJ, Cwyfan-Hughes S \& Holly JMP 1996 Local disruption of the insulin-like growth factor system in the arthritic joint. Arthritis and Rheumatism 39 1556-1565.

Fowlkes JL, Suzuki K, Nagase H \& Thrailkill KM 1994 Proteolysis of insulin-like growth factor-binding protein-3 during rat pregnancy: a role for matrix metalloproteinases. Endocrinology 135 $2810-2813$

Hardingham TE, Bayliss MT, Rayan V \& Noble DP 1992 Effects of growth factors and cytokines on proteoglycan turnover in articular cartilage. British Journal of Rheumatology 31 (suppl 1) 1-6. 
Harris ED 1990 Rheumatoid arthritis. Pathophysiology and implications for therapy. New England Journal of Medicine 322 1277-1289.

Helle SI, Ankler GB, Meadows KA, Holly JMP \& Lonning PE 1998 Alterations in the insulin-like growth factor system during the menstrual cycle in normal women. Maturitas 28 259-265.

Hossenlopp P, Segovia B, Lassarre C, Roghani M, Bredon M \& Binoux M 1990 Evidence of enzymatic degradation of insulin-like growth factor-binding proteins in the $150 \mathrm{~K}$ complex during pregnancy. Journal of Clinical Endocrinology and Metabolism 71 797-805.

Howell DS \& Pelletier JP 1993 Etiopathogenesis of OA. In Arthritis and Allied Conditions, edn 12, pp 21-29. Eds DJ McCarty \& WJ Koopman. Philadelphia: Lea and Febiger.

Jones JI \& Clemmons DR 1995 Insulin-like growth factors and their binding proteins: biological actions. Endocrine Reviews 16 3-34.

Keyszer GM, Heer AH, Kriegsmann J, Geiler T, Keysser C, Gay RE \& Gay S 1995 Detection of insulin-like growth factor-I and II (IGF-I,II) in synovial tissue specimens of patients with rheumatoid arthritis and osteoarthritis by in situ hybridisation. Journal of Rheumatology 22 375-381.

Kubler B, Cowell S, Zapf J \& Braulke T 1998 Proteolysis of insulinlike growth factor binding proteins by a novel 50 kilodalton metalloproteinase in human pregnancy serum. Endocrinology 139 1556-1563.

Kusada J, Otsuka T, Matsui N, Hirano T, Asai K \& Kato T 1993 Immuno-reactive human epidermal growth factor (h-EGF) in rheumatoid synovial fluids. Journal of the Japanese Orthopaedic Association 67 859-865.

Lamson G, Giudice LC \& Rosenfeld RG 1991 A simple assay for proteolysis of IGFBP-3. Journal of Clinical Endocrinology and Metabolism 72 1391-1393.

Lawrence JB, Oxvig C, Overgaard MT, Sottrup-Jensen L, Gleich GJ, Hays LG, Yates JR \& Conover CA 1999 The insulin-like growth factor (IGF)-dependent IGF binding protein-4 protease secreted by human fibroblasts is pregnancy-associated plasma protein-A. PNAS 96 3149-3153.

Lefebvre I, Peeters-Joris C \& Vaes G 1990 Modulation by interleukin-1 and tumor necrosis factor alpha of production of collagenase, tissue inhibitor of metalloproteinases and collagen types in differentiated and dedifferentiated articular chondrocytes. Biochimica et Biophysica Acta 1052 366-378.

MacNaul KL, Chartrain N, Lark M, Tocci MJ \& Hutchinson NI 1990 Discoordinate expression of stromelysin, collagenase, and tissue inhibitor of metalloproteinases- 1 in rheumatoid human synovial fibroblasts. Journal of Biological Chemistry 265 1723817245.

McQuillan DJ, Handley CJ \& Robinson HC 1986a Control of proteoglycan biosynthesis. Biochemical Journal 237 741-747.

McQuillan DJ, Handley CJ, Campbell MA, Bolis S, Milway VE \& Herington AC $1986 b$ Stimulation of proteoglycan biosynthesis by serum and insulin-like growth factor- 1 in cultured bovine articular cartilage. Biochemical Journal 240 423-430.

Maile LA, Xu S, Cwyfan-Hughes SC, Fernihough JK, Pell JM \& Holly JMP 1998 Active and inhibitory components of the insulinlike growth factor binding protein-3 protease system in adult serum, interstitial and synovial fluid. Endocrinology 139 4772-4781.

Matsumoto T, Tsukazaki T, Enomoto H, Iwasaki K \& Yamashita S 1994 Effects of interleukin-1 beta on insulin-like growth factor-I autocrine/paracrine axis in cultured rat articular chondrocytes. Annals of the Rheumatic Diseases $\mathbf{5 3}$ 128-133.

Matsumoto T, Gargosky SE, Iwasaki K \& Rosenfeld RG 1996 Identification and characterisation of insulin-like growth factors (IGFs), IGF-binding proteins (IGFBPs), and IGFBP proteases in human synovial fluid. Journal of Clinical Endocrinology and Metabolism 81 150-155.
Morales TI \& Hascall VC 1989 Factors involved in the regulation of proteoglycan metabolism in articular cartilage. Arthritis and Rheumatism 32 1197-1201.

Mort JS, Dodge GR, Roughley PJ, Liu J, Finch SJ, DiPasquale G \& Poole AR 1993 Direct evidence for active metalloproteinases mediating matrix degradation in interleukin-1 stimulated human articular cartilage. Matrix 13 95-102.

Mow VC, Ratcliffe A \& Poole AR 1992 Cartilage and diarthrodial joints as paradigms for hierarchical materials and structures. Biomaterials 13 67-97.

Neidel J, Blum WF, Schaeffer HJ, Schulze M, Schonau E, Lindschau J \& Foll J 1997 Elevated levels of insulin-like growth factor (IGF) binding protein-3 in rheumatoid arthritis synovial fluid inhibit stimulation by IGF-I of articular chondrocyte proteoglycan synthesis. Rheumatology International 17 29-37.

Pelletier JP, DiBattista JA, Roughley P, McCollum R \& MartelPelletier J 1993 Cytokines and inflammation in cartilage degradation. Rheumatic Disease Clinics of North America 19 545-568.

Roitt I, Brostoff J \& Male D 1989 The complement system. In Immunology, edn 2, pp 164-170. London: Gower Medical Publishing.

Schalkwijk J, Joosten LAB, van den Berg WB, van Wyk JJ \& van de Putte LBA 1989 Insulin-like growth factor stimulation of chondrocyte proteoglycan synthesis by human synovial fluid. Arthritis and Rheumatism 32 66-70.

Schneiderman R, Snir E, Popper O, Hiss J, Stein H \& Maroudas A 1995 Insulin-like growth factor-I and its complexes in normal human articular cartilage: studies of partition and diffusion. Archives of Biochemistry and Biophysics 324 159-172.

Stevens CR, Blake DR, Merry P, Revell PA \& Levick JR 1991 A comparative study by morphometry of the microvasculature in normal and rheumatoid synovium. Arthritis and Rheumatism 34 1508-1513.

Szekanecz Z, Haines GK, Harlow LA, Shah MR, Fong TW, Fu R, Lin SJ, Rayan G \& Koch AE 1995 Increased synovial expression of transforming growth factor (TGF)-beta receptor endoglin and TGF-beta 1 in rheumatoid arthritis: possible interactions in the pathogenesis of the disease. Clinical Immunology and Immunopathology 76 187-194.

Tavera C, Abribat T, Reboul P, Dore S, Brazeau P, Pelletier JP \& Pelletier JM 1996 IGF and IGF-binding protein system in the synovial fluid of osteoarthritic and rheumatoid arthritic patients. Osteoarthritis and Cartilage 4 263-274.

Trippel SB 1995 Growth factor actions on articular cartilage. Journal of Rheumatology 22 (suppl 43) 129-132.

Tyler JA 1989 Insulin-like growth factor 1 can decrease degradation and promote synthesis of proteoglycan in cartilage exposed to cytokines. Biochemical Journal 260 543-548.

Van de Loo AAJ, Joosten LAB, Van Lent PLEM, Arntz OJ \& Van den Berg WB 1995 Role of interleukin-1, tumor necrosis factor- $\alpha$, and interleukin- 6 in cartilage proteoglycan metabolism and destruction: effect of in vivo blocking in murine antigenand zymosan-induced arthritis. Arthritis and Rheumatism $\mathbf{3 8}$ 164-172.

Verschure PJ, van Noorden CJF, van Marle J \& van den Berg WB 1996 Articular cartilage destruction in experimental inflammatory arthritis: insulin-like growth factor-1 regulation of proteoglycan metabolism in chondrocytes. Histochemical Journal 28 835-857.

Vetter U, Zapf J, Heit W, Helbing G, Heinze E, Froesch ER \& Teller WM 1986 Human fetal and adult chondrocytes: effect of insulin-like growth factors I and II, insulin, and growth hormone on clonal growth. Journal of Clinical Investigation 77 1903-1908.

Virca GD, Mallya RK, Pepys MB \& Schnebli HP 1984 Quantitation of human leukocyte elastase, cathepsin G, $\alpha-2$ macroglobulin and $\alpha-1$ proteinase inhibitor in osteoarthritis and rheumatoid arthritis synovial fluids. Advances in Experimental Medicine and Biology 167 345-353. 
Willis DH Jr \& Liberti JP 1985 Post-receptor actions of somatomedin on chondrocyte collagen biosynthesis. Biochimica et Biophysica Acta $84472-80$.

Yateman ME, Claffey DC, Cwyfan-Hughes SC, Frost VJ, Wass JA \& Holly JM 1993 Cytokines modulate the sensitivity of human fibroblasts to stimulation with insulin-like growth factor-I (IGF-I) by altering endogenous IGF-binding protein production. Journal of Endocrinology 137 151-159.

Received 1 November 1999

Revised manuscript received 25 January 2000

Accepted 8 February 2000 